\title{
Myco-Suppression Analysis of Soybean (Glycine max) Damping-Off Caused by Pythium aphanidermatum
}

\author{
Shaban R. M. Sayed ${ }^{1}$, Shaimaa A. M. Abdelmohsen ${ }^{2, *}$, Hani M. A. Abdelzaher ${ }^{3}$, Mohammed A. Elnaghy ${ }^{4}$, Ashraf \\ A. Mostafa ${ }^{5}$, Fatemah F. Al-Harbi ${ }^{2}$ and Ashraf M. M. Abdelbacki ${ }^{6}$ (D) \\ 1 Electron Microscope Unit, Collage of Science, King Saud University, Riyadh 11451, Saudi Arabia; \\ shmohamed@ksu.edu.sa \\ 2 Physics Department, Faculty of Science, Princess Nourah Bint Abdulrahman University, \\ Riyadh 84428, Saudi Arabia; ffalharbi@pnu.edu.sa \\ 3 Department of Biology, Collage of Science, Jouf University, Sakaka 42421, Saudi Arabia; hmdaher@ju.edu.sa \\ 4 Department Botany and Microbiology, College of Science, Minia University, El-Minia 61519, Egypt; \\ mohamed.elnag1hi@mu.edu.eg \\ 5 Botany and Microbiology Department, College of Science, King Saud University, Riyadh 11451, Saudi Arabia; \\ asali@ksu.edu.sa \\ 6 Plant Pathology Department, Faculty of Agriculture, Cairo University, Giza 12613, Egypt; \\ amaeg@hotmail.com \\ * Correspondence: shamohamed@pnu.edu.sa
}

check for updates

Citation: Sayed, S.R.M.; Abdelmohsen, S.A.M.; Abdelzaher, H.M.A.; Elnaghy, M.A.; Mostafa, A.A.; Al-Harbi, F.F.; Abdelbacki, A.M.M. Myco-Suppression Analysis of Soybean (Glycine max) Damping-Off Caused by Pythium aphanidermatum. Plants 2021, 10, 788. https://doi.org/ $10.3390 /$ plants 10040788

Academic Editor: Artur Alves

Received: 24 February 2021

Accepted: 12 April 2021

Published: 16 April 2021

Publisher's Note: MDPI stays neutral with regard to jurisdictional claims in published maps and institutional affiliations.

Copyright: (c) 2021 by the authors. Licensee MDPI, Basel, Switzerland. This article is an open access article distributed under the terms and conditions of the Creative Commons Attribution (CC BY) license (https:// creativecommons.org/licenses/by/ $4.0 /)$.

\begin{abstract}
The role of Pythium oligandrum as a biocontrol agent against Pythium aphanidermatum was investigated to avoid the harmful impacts of fungicides. Three isolates of P. oligandrum (MS15, MS19, and MS31) were assessed facing the plant pathogenic P. aphanidermatum the causal agent of Glycine max damping-off. The tested Pythium species were recognized according to their cultural and microscopic characterizations. The identification was confirmed through sequencing of rDNA-ITS regions including the $5.8 \mathrm{~S}$ rDNA. The biocontrol agent, $P$. oligandrum, isolates decreased the mycelial growth of the pathogenic P. aphanidermatum with $71.3 \%, 67.1 \%$, and $68.7 \%$ through mycoparasitism on CMA plates. While the half-strength millipore sterilized filtrates of P. oligandrum isolates degrade the pathogenic mycelial linear growth by $34.1 \%, 32.5 \%$, and $31.7 \%$, and reduce the mycelial dry weight of the pathogenic P. aphanidermatum by $40.1 \%, 37.4 \%$, and $36.8 \%$, respectively. Scanning electron microscopy (SEM) of the most effective antagonistic P. oligandrum isolate (MS15) interaction showed coiling, haustorial parts of P. oligandrum to P. aphanidermatum hyphae. Furthermore, P. oligandrum isolates were proven to enhance the germination of Glycine max seedling to $93.3 \%$ in damping-off infection using agar pots and promote germination of up to $80 \%$ during soil pot assay. On the other hand, P. oligandrum isolates increase the shoot, root lengths, and the number of lateral roots.
\end{abstract}

Keywords: biological control; biomaterials; damping-off; Glycine max; P. oligandrum; P. aphanidermatum

\section{Introduction}

Soybean (Glycine max L.) is one of the most common widely cultivated food species in the world [1]. Root rot diseases of G. max are widespread in the world and are usually recognized as the main constraint to decrease both yield and quality [2,3]. Pythium as a causal agent for Glycine max root rots has been mentioned as being the main reason leading to soybean yield losses in numerous countries [4,5]. Pythium aphanidermatum has been reported as the species most frequently causing root rot diseases for the greatest variety of crops [4]. The use of chemical fungicides controlling such diseases could lead to degenerating human health, environmental pollution, and the development of pathogen resistance to fungicides. Biological methods are needed for plant protection which are less dependent on chemicals and are more environmentally favorable [5,6].

Pythium is a complex genus, spread worldwide including over 200 species with a wide host range and maintaining in a variety of soil and water environments $[7,8]$. Sev- 
eral researchers have explained that Pythium oligandrum efficiency in controlling plant disease, some of them reported that the antagonistic of P. oligandrum enhance plant immune systems through secretion of an elicitin-like protein that induces plant resistances against different phytopathogenic fungi, avoiding their infection. The biocontrol activity of P. oligandrum attributed to directly attack a group of soil-borne fungal pathogens through; (1) mycoparasitism, (2) colonizing rhizosphere of crop plants and competing for space and nutrients, (3) production of an auxin like tryptophan and indolacetaldhyde, which convert to tryptamine (TNH2) that promote plant growth, and (4) secretion of oligandrin and elicitin-like protein activate plant immune-system that increase crop protection against phytopathogenic microbes [4,9-12]. A similar mode of action observed by other biocontrol agents like Trichoderma harzianum induces systematic resistance in G. max plants and enhances plant growth through elicitation of bioactive metabolites [13-15].

Horner et al. [16] explained the mycoparasitic ability of P. oligandrum through coiling P. oligandrum hyphae around phytophthora hyphae and by secretion of glucanases, cellulose, chitinase and, protease enzymes which degraded the pathogen cell wall. P. oligandrum used in biocontrol of black scurf in potato as the hyphal of biocontrol agent had colonized the sclerotia and established close contact by coiling around the R. solani [17]. Phytium oligandrum has taken serious attention as a biocontrol agent against damping-off diseases, especially those caused by P. aphanidermatum [8,16,18,19].

No attempts have been made to evaluate $P$. oligandrum as a biocontrol agent against $P$. aphanidermatum, the causal factor of G. max seedlings damping-off in Egypt and Saudi Arabia. The present work was, therefore, aimed at evaluating the efficiency of using P. oligandrum in the biocontrol of soybean seedling damping-off caused by P. aphanidermatum.

\section{Results}

Isolation and identification of biocontrol Pythium isolates showed the presence of three strains of P. oligandrum (MS15, MS19, and MS31) obtained from the rhizosphere soil of Raphanus sativus, Eruca sativa, and Allium cepa, respectively, during the survey of Pythium species in El-Minia Governorate, Egypt. These three isolates were identified morphologically as P. oligandrum Drechsler (Figure 1a). In addition, the sequencing of rDNA-ITS for these isolates was closely related to P. oligandrum with $99.9 \%$ similarity to Genbank accession number (AY986954.1).

Isolation of pathogenic strains from the infected roots and seedlings of G. max indicated that $P$. aphanidermatum was the only fungus present in infected tissues. The morphological identification of pathogenic P. aphanidermatum was illustrated in Figure $1 \mathrm{~b}$ and the genetic criteria of this isolate were closely related to P. aphanidermatum with $99.9 \%$ similarity to Genbank accession number (AB274404).

Antagonistic activity of P. oligandrum isolates (MS15, MS19, and MS31) against the pathogenic $P$. aphanidermatum using dual culture technique was reported in Table 1 . The bioactivity assay showed that P. oligandrum isolates decreased the mycelial growth of P. aphanidermatum and the MS15 was the highest one after 3 days of incubation and reduced the growth by $67.2 \%$. Moreover, the reduction in the growth of pathogenic P. aphanidermatum was increased by increasing the incubation time, where the inhibition reached $71.3 \%$ for MS15 after 6 days of incubation, while the results of the isolates (MS19 and MS31) were less effective in all treatments (Table 1). 

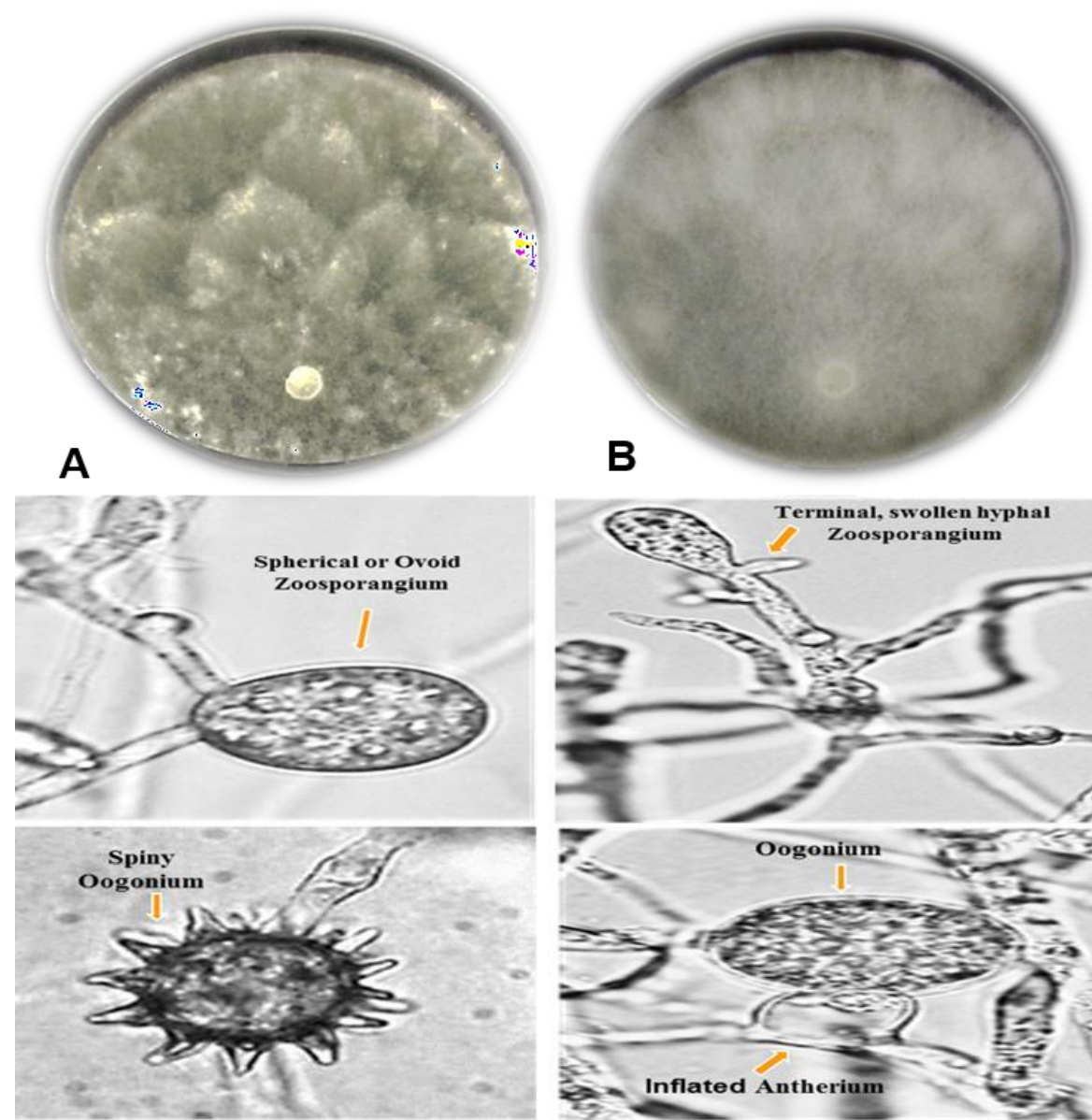

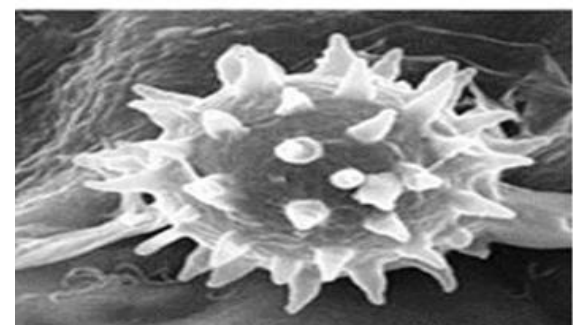

P. oligandrium

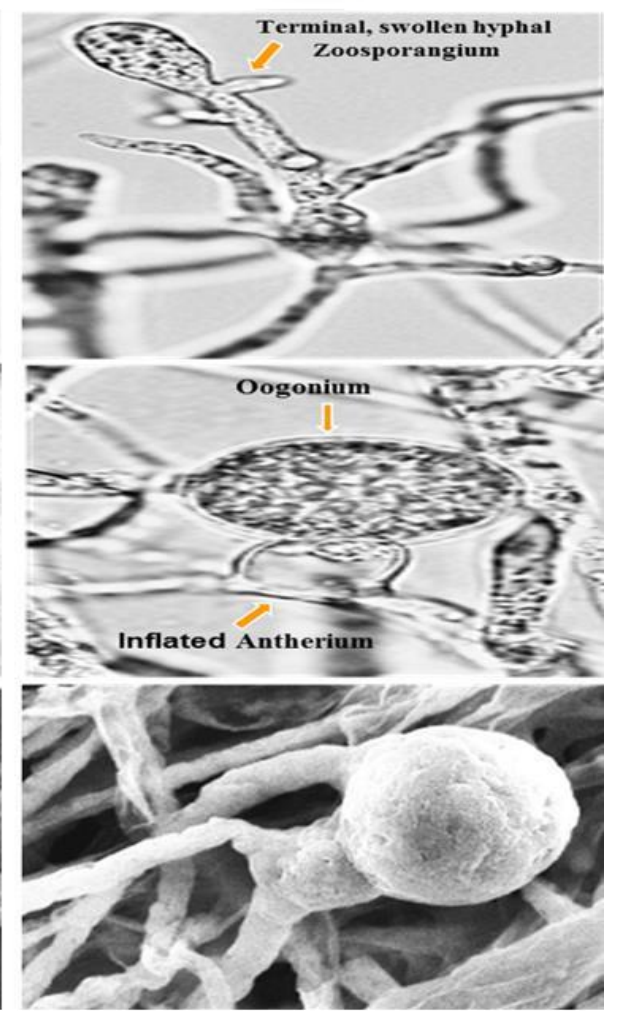

P. aphanidermatum

Figure 1. Morphological characterizations of Pythium isolates on PDA, light, and scanning electron microscope. (A) P. oligandrum and (B) P. aphanidermatum.

The effect of half-strength culture filtrates of bioagent P. oligandrum isolates on mycelial growth of pathogenic $P$. aphanidermatum using solid media revealed that the millipore sterilized half-strength filtrates of P. oligandrum isolates were more effective in reducing the mycelial growth of P. aphanidermatum than that of autoclaved cultured filtrate recording inhibition of mycelial growth of P. aphanidermatum by $34.1 \%, 32.5 \%$, and $31.7 \%$, respectively (Table 2). 
Table 1. The reduction in mycelial growth of the pathogenic P. aphanidermatum by P. oligandrum isolates (MS15, MS19, and MS31).

\begin{tabular}{cccc}
\hline \multirow{2}{*}{ Incubation Period } & Antagonistic isolates & \multicolumn{2}{c}{ P. aphanidermatum } \\
\cline { 2 - 4 } & & Linear Growth $\mathbf{( m m )}$ & Reduction (\%) \\
\hline \multirow{3}{*}{3 days } & P. oligandrum MS15 & $29.52^{*} \pm 0.13$ & 67.2 \\
& P. oligandrum MS19 & $30.51 * \pm 0.16$ & 66.1 \\
& P. oligandrum MS31 & $31.23 * \pm 0.15$ & 65.3 \\
\hline \multirow{2}{*}{6 days } & P. oligandrum MS15 & $25.83 * \pm 0.14$ & 71.3 \\
& P. oligandrum MS19 & $27.01 * \pm 0.05$ & 67.1 \\
\hline \multicolumn{2}{c}{ Control of $P$. aphanidermatum } & $28.17^{*} \pm 0.08$ & 68.7 \\
\hline
\end{tabular}

Data are means of (3) replicates \pm the standard error of the three isolates; values followed by an asterisk $\left(^{*}\right)$ are significantly compared with control at $p \leq 0.05$.

Table 2. Effect of half-strength culture filtrates of P. oligandrum isolates (MS15, MS19 and MS31) on mycelial linear growth of the pathogenic P. aphanidermatum.

\begin{tabular}{|c|c|c|c|}
\hline \multirow{2}{*}{$\begin{array}{c}\text { Type of Culture } \\
\text { Filtrate Sterilization }\end{array}$} & \multirow{2}{*}{$\begin{array}{l}\text { Antagonistic } \\
\text { Isolates }\end{array}$} & \multicolumn{2}{|c|}{ P. aphanidermatum } \\
\hline & & Linear Growth (mm) & Reduction (\%) \\
\hline \multirow{3}{*}{ Millipored filtrate } & P. oligandrum MS15 & $59.24 * \pm 0.15$ & 34.18 \\
\hline & P. oligandrum MS19 & $60.73 * \pm 0.08$ & 32.52 \\
\hline & P. oligandrum MS31 & $61.46^{*} \pm 0.14$ & 31.71 \\
\hline \multirow{3}{*}{ Autoclaved filtrate } & P. oligandrum MS15 & $63.48 * \pm 0.17$ & 29.47 \\
\hline & P. oligandrum MS19 & $65.58 * \pm 0.09$ & 27.13 \\
\hline & P. oligandrum MS31 & $65.84^{*} \pm 0.11$ & 26.84 \\
\hline \multicolumn{2}{|c|}{ Control of P. aphanidermatum } & $90.00 * \pm 0.02$ & - \\
\hline
\end{tabular}

Data are means of (3) replicates \pm the standard error of the three isolates; values followed by an asterisk $\left(^{*}\right)$ are significantly compared with control at $p \leq 0.05$.

The effect of culture filtrates of $P$. oligandrum isolates on the mycelial dry weight of $P$. aphanidermatum using liquid medium reported in Table 3. The millipore sterilized half-strength filtrates of $P$. oligandrum isolates reduce the mycelial dry weight of P. aphanidermatum more effectively than autoclaved filtrate recording $40.1 \%, 37.4 \%$, and $36.8 \%$, respectively, and the height reduction was reported by P. oligandrum $\left(\mathrm{MS}_{15}\right)$.

Table 3. Effect of half-strength culture filtrate of P. oligandrum isolates (MS15, MS19 and MS31) on the mycelial dry weight of the pathogenic P. aphanidermatum.

\begin{tabular}{cccc}
\hline \multirow{2}{*}{$\begin{array}{c}\text { Type of Filtrate } \\
\text { Sterilization }\end{array}$} & $\begin{array}{c}\text { Antagonistic } \\
\text { Isolates }\end{array}$ & \multicolumn{2}{c}{ P. aphanidermatum } \\
\cline { 3 - 4 } & Pycelial Dry Weight (mg) & Inhibition (\%) \\
\hline \multirow{2}{*}{ Millipored filtrate } & P. oligandrum MS15 & $463.62 * \pm 0.17$ & 40.11 \\
& P. oligandrum MS19 & $484.53 * \pm 0.12$ & 37.4 \\
& P. oligandrum MS1 & $489.19 * \pm 0.15$ & 36.8 \\
\hline \multirow{2}{*}{ Autoclaved filtrate } & P. oligandrum MS19 & $597.68 * \pm 0.18$ & 35.7 \\
& P. oligandrum MS31 & $542.57^{*} \pm 0.19$ & 31.6 \\
\hline \multicolumn{2}{c}{ Control P. aphanidermatum } & $774.00 * \pm 0.14$ & 29.9 \\
\hline
\end{tabular}

Data are means of (3) replicates \pm the standard error of the three isolates; values followed by an asterisk $\left(^{*}\right)$ are significantly compared with control at $p \leq 0.05$.

Interaction between the highly effective isolate of P. oligandrum (MS15) and P. aphanidermatum using a light microscope and scanning electron microscope (SEM) were provided in Figures 2 and 3. The characterization of coiling, haustorial branches, infection pegs, and penetration of P. oligandrum to P. aphanidermatum hyphae was shown in the contact area 
between the two Pythia. Pythium oligandrum attacked P. aphanidermatum by entangling its hyphae with either thin haustorial arms or infection pegs reaching finally to its total destruction. These characters of mycoparasitism were showed clearly at the early stages of the contact region between the two colonies of P. oligandrum and P. aphanidermatum on the surface of Corn Meal Agar CMA plates.
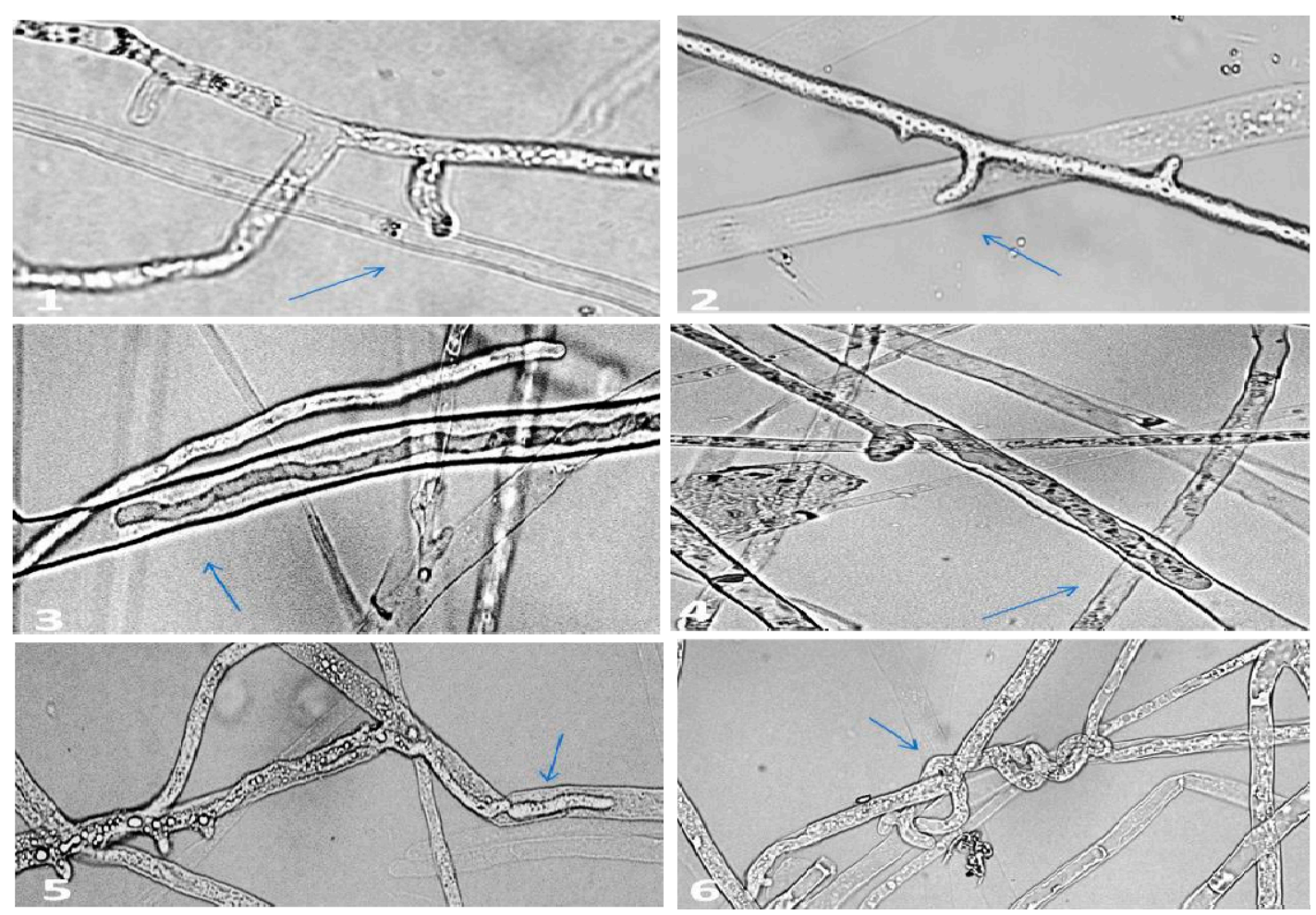

Figure 2. Hyphal interactions between P. oligandrum (MS15) and P. aphanidermatum using a light microscope: (1) and (2) showing infection pegs of P. oligandrum; (3) and (4) showing hyphae of P. oligandrum grow inside hyphae of P. aphanidermatum; (5) and (6) arrows pointed to P. oligandrum twisted on hyphae of P. aphanidermatum.

Pathogenicity of P. aphanidermatum and its possible control measure by P. oligandrum isolates (MS15, MS19, and MS31) in both agar bottles and soil pots assay were illustrated in Table 4 and Figure 4. It was found that the pathogenic isolate of P. aphanidermatum was highly pathogenic causing $100 \%$ and $86.7 \%$ seedling damping-off when the pathogen cultured with seedlings alone in both $2 \% \mathrm{WA}$ and soil pots respectively. In contrast, the three isolates of the biocontrol P. oligandrum isolates were detected to be non-pathogenic to G. max seedlings and also improve the seedling growth more than the control treatment. On the other hand, the application of the biocontrol P. oligandrum isolates inhibited the seedling damping-off by $93.3 \%, 87.2 \%$, and $86.7 \%$ in $2 \%$ WA assay and $80 \%, 75.1 \%$, and $76.7 \%$, respectively in soil pots compared with the control. Moreover, P. oligandrum isolate (MS15) was the most effective isolate in both treatments. 

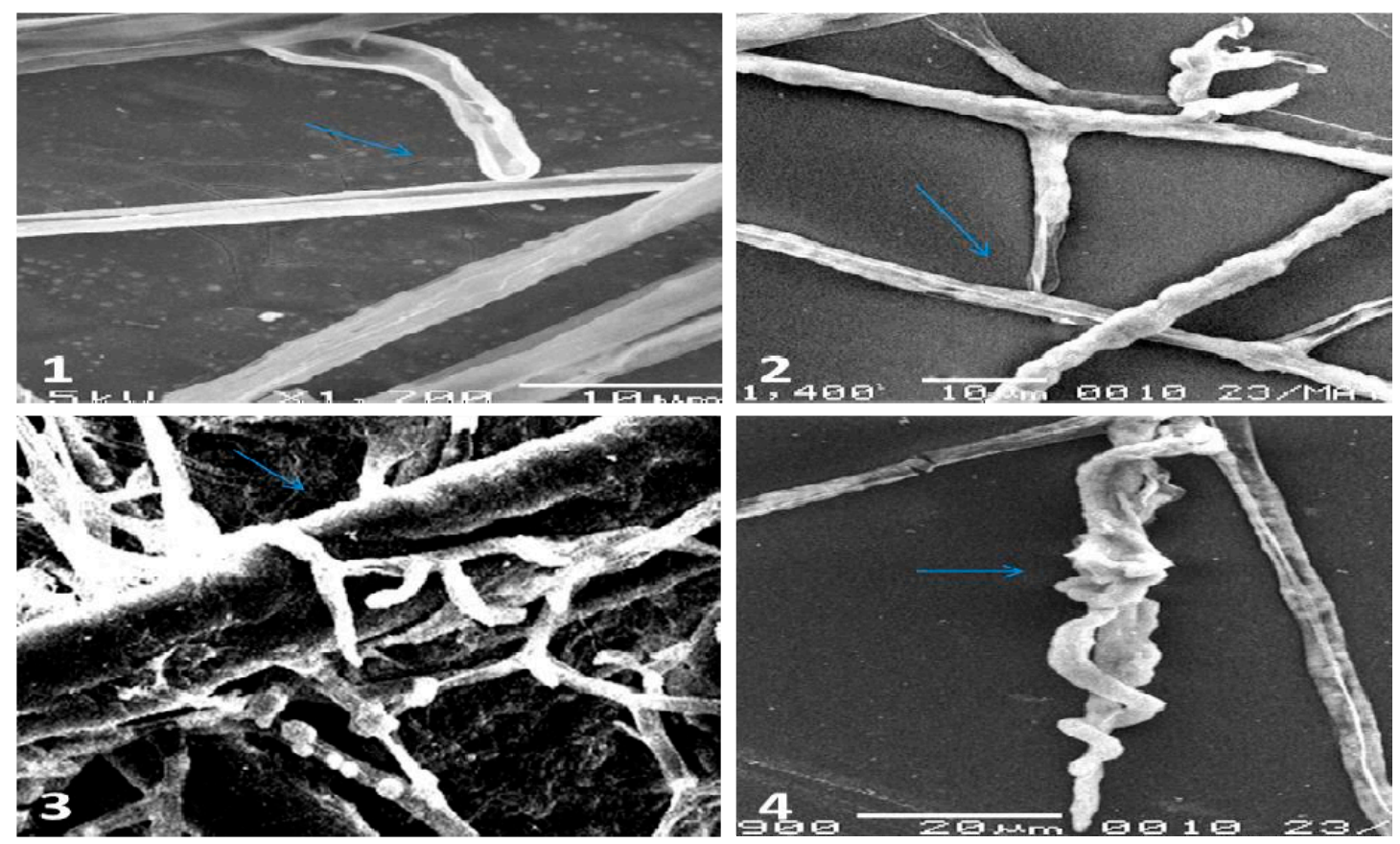

Figure 3. Hyphal interactions between P. oligandrum (MS15) and P. aphanidermatum using SEM: (1) and (2) showing infection pegs of P. oligandrum; (3) and (4) showing torsion of P. oligandrum hyphae P. aphanidermatum and the arrow pointed to hyphal collapse and turgor loss of P. aphanidermatum hyphae.

Table 4. Effect of P. oligandrum isolates on G. max pre-emergence damping-off disease grown in $2 \%$ water agar and in soil pots.

\begin{tabular}{|c|c|c|c|c|}
\hline \multirow{3}{*}{ Treatments } & \multicolumn{4}{|c|}{ Glycine max Seedlings } \\
\hline & \multicolumn{2}{|c|}{$2 \%$ Water Agar } & \multicolumn{2}{|c|}{ Soil Pots } \\
\hline & Inhibition (\%) & Survival (\%) & Inhibition (\%) & Survival (\%) \\
\hline Control (No Pythium) & 0 & 100 & 00 & 100 \\
\hline P. aphanidermatum & 100 & 00 & 86.7 & 13.3 \\
\hline P. oligandrum MS15 & 0 & 100 & 0 & 100 \\
\hline P. oligandrum MS19 & 0 & 100 & 0 & 100 \\
\hline P. oligandrum MS31 & 0 & 100 & 0 & 100 \\
\hline $\begin{array}{l}\text { P. aphanidermatum + } \\
\text { P. oligandrum MS15 }\end{array}$ & 0.67 & 93.3 & 20 & 80 \\
\hline $\begin{array}{l}\text { P. aphanidermatum + } \\
\text { P. oligandrum MS19 }\end{array}$ & 12.7 & 87.2 & 24.9 & 75.1 \\
\hline $\begin{array}{l}\text { P. aphanidermatum + } \\
\text { P. oligandrum MS31 }\end{array}$ & 13.3 & 86.7 & 23.3 & 76.7 \\
\hline
\end{tabular}

The effect of P. oligandrum on the growth parameters of the G. max seedling was recorded in Table 5 and illustrated in Figures 5 and 6 . The results showed that the growth parameters of the treated plants with P. oligandrum isolates were enhanced by increasing the shoot and root lengths and increasing the number of lateral roots in all treatments of bioagent isolates. The phytopathogenic P. aphanidermatum affected seedling growth of G. max seeds and reduced their shoot and root length by $43.3 \%$ and $34.9 \%$, respectively, as shown in Figure 6 when compared with the healthy plants (no Pythium) in Table 5. 

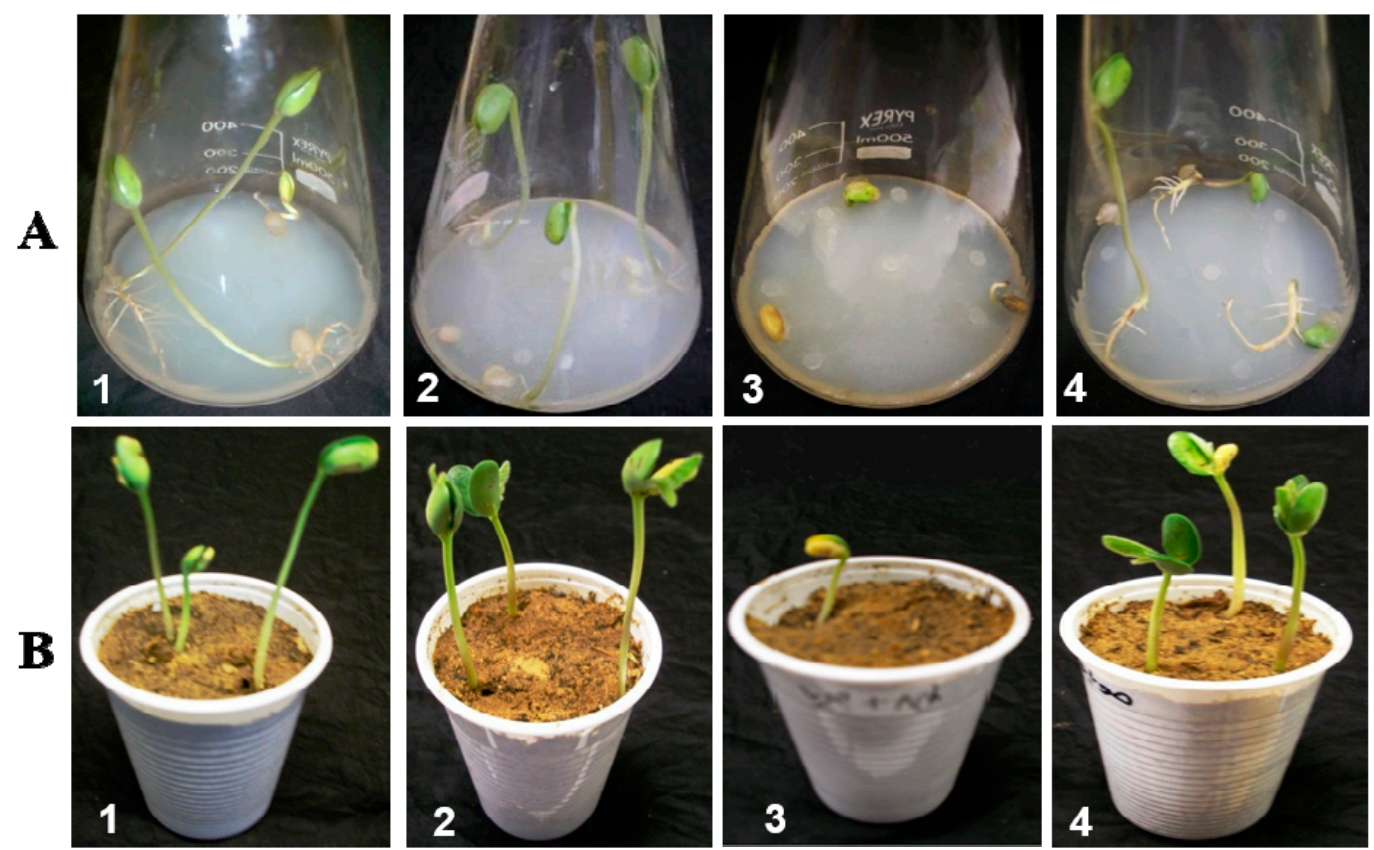

Figure 4. Bioactivity of P. oligandrum $\left(\mathrm{MS}_{15}\right)$ on P. aphanidermatum through the cultivation of G. max seeds on $2 \%$ water agar medium (A) and soil pots (B): 1, seeds cultivated alone as a control; 2, seeds cultivated with P. oligandrum alone; 3, seeds cultivated with P. aphanidermatum alone; 4 , seeds cultivated with both of P. oligandrum and P. aphanidermatum.

Table 5. Effects of G. max seed treatment with three isolates of bioagent P. oligandrum on the growth seed parameters.

\begin{tabular}{|c|c|c|c|c|c|c|}
\hline \multirow[b]{2}{*}{ Seed Treatments } & \multicolumn{3}{|c|}{ Plant Growth Parameters } & \multicolumn{3}{|c|}{ Percentage of Plant Growth Promotion } \\
\hline & $\begin{array}{c}\text { Shoot } \\
\text { Length }(\mathrm{cm})\end{array}$ & $\begin{array}{c}\text { Root } \\
\text { Length }(\mathrm{cm})\end{array}$ & $\begin{array}{c}\text { No. of } \\
\text { Lateral Roots }\end{array}$ & $\begin{array}{c}\text { Shoot } \\
\text { Length (\%) }\end{array}$ & $\begin{array}{c}\text { Root } \\
\text { Length }(\%)\end{array}$ & $\begin{array}{l}\text { No. of Lateral } \\
\text { Roots (\%) }\end{array}$ \\
\hline Control (No Pythium) & $17.1 * \pm 0.7$ & $4.3^{*} \pm 0.6$ & $11.7^{*} \pm 1.1$ & 00 & 00 & 00 \\
\hline P. oligandrum MS15 & $18.7^{*} \pm 1.1$ & $8.5 * \pm 0.9$ & $22.3^{*} \pm 1.3$ & 8.6 & 97.7 & 90.6 \\
\hline P. oligandrum MS19 & $17.9 * \pm 0.9$ & $7.1^{*} \pm 1.3$ & $19.4 * \pm 0.9$ & 4.7 & 65.1 & 65.8 \\
\hline P. oligandrum MS31 & $18.5^{*} \pm 1.2$ & $7.8 * \pm 0.8$ & $21.5^{*} \pm 1.2$ & 8.2 & 81.4 & 83.8 \\
\hline
\end{tabular}

Data are means of (3) replicates \pm the standard error of the three isolates; values followed by an asterisk $(*)$ are significantly compared with control at $p \leq 0.05$. 


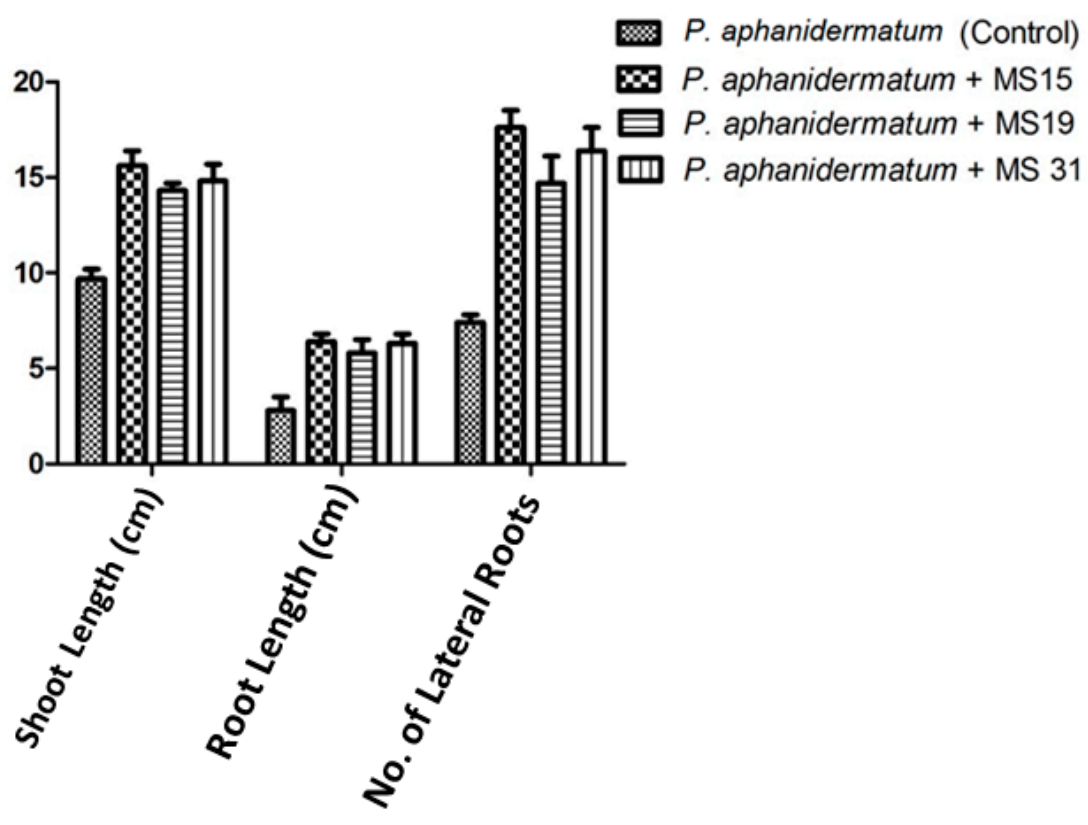

Figure 5. Effects of G. max seed treatment with the pathogenic P. aphanidermatum and three isolates of P. oligandrum (MS15, MS19, and MS31) on growth seed parameters. (Data are means of (3) replicates; values are significantly compared with control at $p \leq 0.05)$.

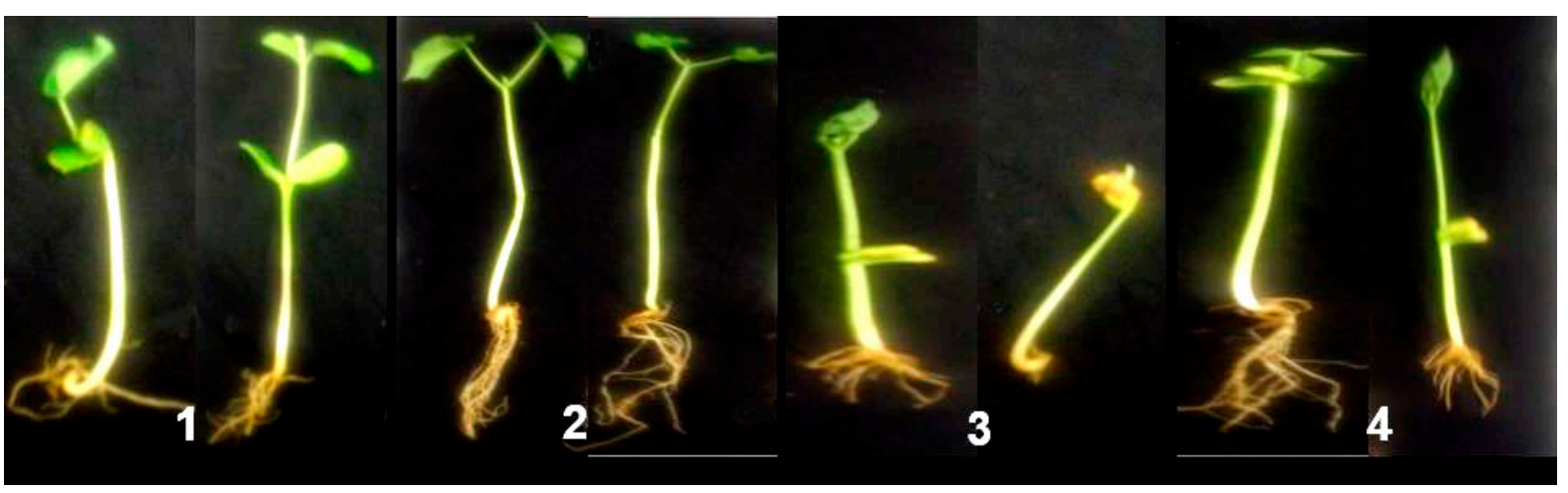

Figure 6. Growth of G. max seedling parameters: (1), uninfected seedlings (negative control); (2), seedlings cultivated with P. oligandrum (positive control); (3), seedling infested with P. aphanidermatum alone and (4), seedling infested with both P. oligandrum and P. aphanidermatum.

\section{Discussion}

Root damping-off diseases are widely disturbed all over the world and are recognized as a serious problem to soybean cultivators, as they significantly decrease the bean yield. Several control measures of the disease are available, including fungicidal control, enhancement of genetic resistance, which may lead to deteriorating human health [5,20]. In Egypt, there is no active control method to reduce damping-off of many crops and vegetable plants caused by P. aphanidermatum although, that pathogenic is widely distributed throughout the country $[17,18,21,22]$. However, fungicides are regularly used by farmers to manage such diseases without obvious results [6,23]. Pythium aphanidermatum was isolated in this study as the causal agent of G. max damping-off and the pathogenicity test concerned with the pathogenic isolate of P. aphanidermatum was highly virulent to G. max seedlings causing $100 \%$ damping off. In contrast, the three isolates of P. oligandrum (MS15, MS19, and MS31) were found to be non-pathogenic and promote seed germination [24,25]. This result was in agreement with the result of Nzungize et al. [20,26]. 
Biological control of damping-off diseases is a complicated process as a result of the pathogens occurs surroundings the rhizosphere interface. The rhizosphere is indicated by intense microbial action including, a high population of microorganisms, salt concentrations, and osmotic and water potential [27]. The efficient microorganisms for biological control of phytopathogenic fungi include some Pythium spp. as P. oligandrum. The biocontrol agent can preserve the plant from fungal infection through competition with the pathogen for nutrients, the production of antifungal metabolites, parasitism (lysis of the pathogen), or through enhancement of the plant resistance mechanisms [11,27]. The growth of $P$. aphanidermatum was successfully inhibited by P. oligandrum isolates with growth reductions reached $71.3 \%$ with $P$. oligandrum MS15. The millipore sterilized half-strength filtrate of the bioactive P. oligandrum MS15 showed more activity (34.1\%) compared with autoclaved filtrates in the linear growth reduction of pathogenic P. aphanidermatum, which reach $29.4 \%$. These results were confirmed through the reduction of the mycelial dry weight of pathogenic $P$. aphanidermatum with half-strength millipore sterilized filtrates of the bioactive P. oligandrum MS15 to $40.11 \%$ compared with autoclaved filtrate (35.7\%). That explains the low activity of autoclaved P. oligandrum filtrates, which may affect and destroy the active metabolites [28-31].

P. oligandrum isolates (MS15, MS19, MS31) parasitized hyphae of P. aphanidermatum by entangling the hyphae of $P$. aphanidermatum with thin haustorial branches or infection pegs, eventually leading to destruction, revealing the mode of action of antagonism between P. oligandrum and P. aphanidermatum [20,29] as appears in our results of screening for hyphal interaction under light and scanning microscopy. There were at least three known modes of P. oligandrum action on plant pathogens: mycoparasitism mediated by intimate hyphae interactions, antibiosis and enhancement of plant resistance due to protein metabolite (oligandrin) production [8]. The coiling and penetration of $P$. oligandrum hyphae to $P$. aphanidermatum hyphae observed in this study had frequently been reported $[17,20]$. Additionally, the isolate MS15 of P. oligandrum was the most effective antagonistic one and reduced the disease severity of $P$. aphanidermatum infected G. max to $93.3 \%$ in agar bottles and $80 \%$ in soil pots assay. These results confirm the ability of P. oligandrum to significantly reduce the infection by $P$. aphanidermatum $[14,21]$. Moreover, the biocontrol agent $P$. oligandrum was proved to enhance the growth of G. max seedling. These growth promotions of P. oligandrum may be attributed to the elicitation of bioactive fungal metabolites $[14,15]$. It can be concluded that $P$. oligandrum isolated in this study worked as mycoparasite and antifungal metabolites producer, which suppresses the plant-parasitic $P$. aphanidermatum.

The present study confirmed the efficiency and importance of P. oligandrum as a biological control against root diseases avoiding biohazards of fungicides usages.

\section{Materials and Methods}

The method of zoospores baiting technique (ZBT) was used for isolation of the biocontrol agent $P$. oligandrum during the survey of Pythium species associated with the rhizosphere soil of Raphanus sativus, Eruca sativa, and Allium cepa in El-Minia governorate, Egypt during the spring of 2016. The isolation was done using Nystatin Ampicillin Rifampcin Miconazole (NARM) selective medium which was described by Senda et al. [32].

Rotten roots and basal parts of diseased seedling of G. max were collected in March of 2016 from a field in Kidwan, El-Minia governorate, Egypt (Figure 1) and used for isolation of pathogenic $P$. aphanidermatum. The deceased tissues were cleaned with $50 \%$ ethanol $(v / v)$ for $30 \mathrm{~s}$ accompanied by washing with sterile distilled water, then dried with sterile filter paper and transported to NARM medium [32]. All seeded plats were incubated at $20^{\circ} \mathrm{C}$ and examined daily. Obtained colonies were then purified and subjected to identification.

\subsection{Identification of Pythium Species}

NARM selective medium was found to repress the bacterial growth in Pythium cultures whilst not affecting Pythium itself. The required reproductive fungal structure including the shape, size, and position of sporangia, antheridia, oogonia, oospores, and zoospores 
formation was ascertained in grass blade culture [14,16]. The morphological identification of isolated Pythium species was carried out using the keys of Dick and Plaats-Niterink $[7,33]$. In addition, Pythium species identification was confirmed through the DNA extraction and amplification using polymerase chain reaction (PCR) technique according to [32,34], then the sequencing of rDNA-ITS regions including the 5.8 SrDNA, were analyzed according to the method developed by $[21,35]$ using the basic local alignment search tool (BLAST).

4.2. Antagonistic Activity of P. oligandrum Isolates against the Pathogenic P. aphanidermatum Using Dual Culture Technique

Three isolates of P. oligandrum (MS15, MS19, and MS31) were identified as biocontrol agents. Sterilized PDA plates were inoculated by $5 \mathrm{~mm}$ discs cutting from the margins of each of the pathogenic $P$. aphanidermatum isolate and the three isolates of the biocontrol P. oligandrum at a distance of $4 \mathrm{~cm}$ from each other. Three replicates were managed per each treatment and the plates were incubated at $25^{\circ} \mathrm{C}$ for $3-6$ days. When the growth of control P. aphanidermatum mycelia covers all plates surface, the data were recorded. Percentages of reduction in mycelial growth of the pathogenic P. aphanidermatum were calculated and recorded in relation to the control.

\subsection{Effect of Half-Strength Culture Filtrate of P. oligandrum on the Linear Growth of Pathogenic P. aphanidermatum}

Sterilized filtrate of 5-day old cultures of P. oligandrum isolates grown on potato dextrose broth (PDB) was tested against the growth of pathogenic P. aphanidermatum. The tested filtrates were sterilized by either autoclave or using a $0.22 \mu \mathrm{m}$ millipore filter. Equal volumes of both sterilized filtrates of P. oligandrum isolates and sterilized double strength PDA medium were mixed $(1: 1, v / v)$ before pouring in sterilized Petri dishes. Discs of the 3-day old culture of the pathogenic P. aphanidermatum were put in the middle of these plates and incubated at $25^{\circ} \mathrm{C}$. Data were recorded when the mycelial growth of the control P. aphanidermatum covers all surfaces of plates and of comparing with control, the reduction mycelial growth percentages were recorded [11].

\subsection{Effect of Half-Strength Culture Filtrate of P. oligandrum on the Dry Weight of Pathogenic P. aphanidermatum}

An equal volume of sterilized filtrates (ether by Autoclave or $0.22 \mathrm{Mm}$ millipore) at a rate of $50 \mathrm{~mL}$ was mixed with $50 \mathrm{~mL}$ sterilized double strength of potato dextrose broth (PDB) in $250 \mathrm{~mL}$ Erlenmeyer flasks. Three control flasks containing $50 \mathrm{~mL}$ double-strength PDB medium mixed with $50 \mathrm{~mL}$ of sterile distilled water. Mycelial discs of 5 days old culture of the phytopathogenic $P$. aphanidermatum were inoculated and the flasks were incubated at $25^{\circ} \mathrm{C}$ for 8 days. Mycelium from each flask was filtered using Whatman's No. 2 filter paper, washed and dried in the oven at $80{ }^{\circ} \mathrm{C}$ for $72 \mathrm{~h}$, and finally weighed. All the cultures were maintained in three replicates. The percent inhibition in mycelial dry weight was recorded to indicate the effect of the antagonist's filtrate on the pathogenic fungal growth.

\subsection{Mycoparasitism between P. oligandrum and P. aphanidermatum Using SEM}

Mycelial strips were obtained from the contact area between the two colonies of P. oligandrum and P. aphanidermatum grown on CMA for three days at $25{ }^{\circ} \mathrm{C}$ and then fixed in $2.5 \%$ gluteraldehyde-sodium phosphate buffer $(0.13 \mathrm{M}, \mathrm{Ph} 7.2)$ overnight. The specimens were washed three times with buffer and then postfixed in osmium tetraoxide for $2 \mathrm{~h}$, washed again with buffer, and dehydrated using ascending series of ethanol level (30-100\%) for $15 \mathrm{~min}$ at each step. The specimens were dried at the critical point and coated with carbon to be examined using the scanning electron microscope (JEOL JSM-6380 LA) operating at $20 \mathrm{kV}$ [30]. 


\subsection{Pathogenicity of P. aphanidermatum and Its Possible Control Measure \\ 4.6.1. In Agar Bottles Assay}

Pathogenicity and possible control of P. aphanidermatum using P. oligandrum were investigated according to the method described by Abdelzaher and Kageyam [23]. G. max seeds were surface sterilized and germinated to form radicals and plumules for 3 days at $25^{\circ} \mathrm{C}$, then three viable seeds were grown onto $2 \%$ WA in a $250 \mathrm{~mL}$ Erlenmeyer flask. Three seedling flasks were inoculated by three 5-mm discs cutting from a 5-days old culture of pathogenic $P$. aphanidermatum to evaluate their pathogenicity as a positive control. Other seedling flasks were inoculated by three $5-\mathrm{mm}$ discs of isolates of biocontrol agent P. oligandrum isolates act as a negative control. While the other seedling flasks were inoculated by three discs of each of P. oligandrum isolates and P. aphanidermatum to evaluate the bioactivity of P. oligandrum isolates (MS15, MS19, and MS31). The inoculated flasks were incubated in a growth cabinet at $25^{\circ} \mathrm{C}$ with a $12 \mathrm{~h}$ photoperiod $(91 \mu \mathrm{mol} \mathrm{m}-2 \mathrm{~S}-1)$. Dampingoff was restricted as the difference between seedlings emergence in non-inoculated controls and inoculated one [21]. The treated seedlings flasks were observed to detect damping-off diseases by recording seedling emergence.

\subsubsection{In Soil Pots Assay}

To prepare P. aphanidermatum inoculum, five grams of grass blade leaf fragments $(0.5 \mathrm{~cm} \times 1 \mathrm{~cm})$ and $2 \mathrm{gm}$ glucose were saturated with $10 \mathrm{~mL}$ distilled water in a $250 \mathrm{~mL}$ Erlenmeyer flask. After autoclaving, each flask was inoculated with three discs of P. aphanidermatum, then incubated at $25^{\circ} \mathrm{C}$ for 7 days. Inoculum concentration of $2.5 \%$, was taken by mixing $1 \mathrm{gm}$ of colonized grass leaf fragments in the Erlenmeyer flask with $50 \mathrm{gm}$ of oven-dried ( $70-80^{\circ} \mathrm{C}$ for 2 days) loam sandy soil (LSS) using a sterilized mortar. Two and a half gm of this mixture was added to $97.5 \mathrm{gm}$ of sterilized soil (LSS). Inoculated soil was placed in plastic pots and exterior sterilized seeds of G. max were sowed after viability test as three seeds in each pot. The pots were acted as a positive control of pathogenicity and incubated in a growth cabinet. Damping-off disease severity was determined as mentioned above.

To evaluate the efficacy of P. oligandrum against the damping-off disease of G. max in artificially infested soil with $P$. aphanidermatum, mycelial mats of $P$. oligandrum isolates were got from cultures developed in V-8 juice broth incubated for 10 days in darkness at $25^{\circ} \mathrm{C}$, then the mycelial mats were cleaned with sterile saline water and fragmented by tissue homogenizer. The preparation was utilized to coat G. max seeds using $3 \%$ carboxy methyl cellulose solution (CMC). Mycelial mats of P. oligandrum isolates (MS15, MS19, and MS31) at concentrations of 1000 prop gules per ml were mixed with exterior sterilized seeds of G. max. The seeds were spread in the sterile opened Petri dish to dry overnight in a refrigerator at $5{ }^{\circ} \mathrm{C}$. Three coated seeds of G. max were sown into P. aphanidermatum infested soil at $5 \mathrm{~mm}$ depth from the soil surface as treated pots.

Some non-coated G. max seeds have been sown into infested soil with P. aphanidermatum and used as a positive control. Another group of coated seeds with the biocontrol P. oligandrum was sown in sterilized soil as a negative control. All pots were put in a growth cabinet as reported previously. Numbers of G. max seeds, which damped-off were counted after 14 days from sowing. Experiments were done with ten replicate pots per treatment.

\subsection{Effects of G. max Seeds Treatment with P. aphanidermatum and Three Isolates of Bioagent P. oligandrum on Growth Seed Parameters}

The growth promotion percentage for the shoot length, root length, and the number of lateral roots as growth parameters of the treated plants with the phytopathogenic P. aphanidermatum and P. oligandrum isolates were measured and calculated according to the formula: 
The growth promotion percentage $=\frac{\text { Plant growth of treatment }- \text { Plant growth of control }}{\text { Plant growth of control }} \times 100$

Statistical analyses software, GraphPad Prism 5.0 (GraphPad Software, Inc., La Jolla, CA, USA), was used to statistically analyze the data of antagonistic activity using one-way analysis of variance and Tukey's test. The mean of triplicates was used to tabulate the data $(p<0.05)$.

\section{Conclusions}

The results attained by the present study conclude that $P$. oligandrum exhibited highly potential bioactivity against $P$. aphanidermatum mainly through mycoparasitism. Bioassay of $P$. oligandrum as a control agent showed that bioactivity of P. oligandrum using the dual culture technique was more effective than that of fungal filtrate. The confirmed efficiency of $P$. oligandrum as a biological control against G. max root diseases avoid the biohazards of fungicides application. This efficiency of P. oligandrum as a biological control agent increases the ability of its usage as an effective natural alternative to chemical fungicides used to control G. max damping-off disease.

Author Contributions: Conceptualization, S.R.M.S. and S.A.M.A.; methodology, H.M.A.A. and M.A.E.; software, S.A.M.A.; validation, H.M.A.A. and A.A.M.; formal analysis, F.F.A.-H.; investigation, M.A.E.; resources, S.A.M.A. and F.F.A.-H.; data curation, S.R.M.S.; writing-original draft preparation, S.R.M.S. and S.A.M.A.; writing-review and editing, S.R.M.S., A.A.M., and A.M.M.A.; visualization, H.M.A.A. and A.M.M.A.; supervision, A.M.M.A. and A.A.M.; funding acquisition, S.A.M.A. All authors have read and agreed to the published version of the manuscript.

Funding: This research was funded by the Deanship of Scientific Research at Princess Nourah bint Abdulrahman University through the Fast-track Research Funding Program to support publication in the top journal (Grant no. 42-FTTJ-06).

Institutional Review Board Statement: Not applicable.

Informed Consent Statement: Not applicable.

Acknowledgments: This research was funded by the Deanship of Scientific Research at Princess Nourah bint Abdulrahman University through the Fast-track Research Funding Program to support publications in the top journal (Grant no. 42-FTTJ-06).

Conflicts of Interest: The authors declare no conflict of interest.

\section{References}

1. Urrea, K.; Rupe, J.; Chen, P.; Rothrock, C.S. Characterization of seed rot resistance to Pythium aphanidermatum in soybean. Crop. Sci. 2017, 57, 1394-1403. [CrossRef]

2. Janvier, C.; Villeneuve, F.; Alabouvette, C.; Edel-Hermann, V.; Mateille, T.; Steinberg, C. Soil health through soil disease suppression: Which strategy from descriptors to indicators? Soil Biol. Biochem. 2007, 39, 1-23. [CrossRef]

3. Nzungize, J.; Gepts, P.; Buruchara, R.; Male, A.; Ragama, P.; Busogoro, J.; Baudoin, J.-P. Introgression of Pythium root rot resistance gene into Rwandan susceptible common bean cultivars. Afr. J. Plant. Sci. 2011, 5, 193-200.

4. Navi, S.S.; Huynh, T.; Mayers, C.G.; Yang, X.-B. Diversity of Pythium spp. associated with soybean damping-off, and management implications by using foliar fungicides as seed treatments. Phytopathol. Res. 2019, 1, 1-10. [CrossRef]

5. Vera-Reyes, I.; Esparza-Arredondo, I.J.E.; Lira-Saldivar, R.H.; Granados-Echegoyen, C.A.; Alvarez-Roman, R.; Vásquez-López, A.; De los Santos-Villarreal, G.; Díaz-Barriga Castro, E. In vitro antimicrobial effect of metallic nanoparticles on phytopathogenic strains of crop plants. J. Phytopathol. 2019, 167, 461-469. [CrossRef]

6. Mohiddin, G.J.; Srinivasulu, M.; Subramanyam, K.; Madakka, M.; Meghana, D.; Rangaswamy, V. Influence of insecticides flubendiamide and spinosad on biological activities in tropical black and red clay soils. 3 Biotech. 2015, 5, 13-21. [CrossRef]

7. Ashwathi, S.; Ushamalini, C.; Parthasarathy, S.; Nakkeeran, S. Morphological, pathogenic and molecular characterisation of Pythium aphanidermatum: A causal pathogen of coriander damping-off in India. Pharma Innov. 2017, 6, 44.

8. Kato, M.; Minamida, K.; Tojo, M.; Kokuryu, T.; Hamaguchi, H.; Shimada, S. Association of Pythium and Phytophthora with pre-emergence seedling damping-off of soybean grown in a field converted from a paddy field in Japan. Plant Prod. Sci. 2013, 16, 95-104. [CrossRef]

9. Takenaka, S.; Nakamura, Y.; Kono, T.; Sekiguchi, H.; Masunaka, A.; Takahashi, H. Novel elicitin-like proteins isolated from the cell wall of the biocontrol agent Pythium oligandrum induce defence-related genes in sugar beet. Mol. Plant Pathol. 2006, 7, 325-339. [CrossRef] 
10. Vallance, J.; Le Floch, G.; Déniel, F.; Barbier, G.; Lévesque, C.A.; Rey, P. Influence of Pythium oligandrum biocontrol on fungal and oomycete population dynamics in the rhizosphere. Appl. Environ. Microbiol. 2009, 75, 4790-4800. [CrossRef] [PubMed]

11. Benhamou, N.; Le Floch, G.; Vallance, J.; Gerbore, J.; Grizard, D.; Rey, P. Pythium oligandrum: An example of opportunistic success. Microbiology 2012, 158, 2679-2694. [CrossRef]

12. Patkowska, E. Effect of Bio-Products on Bean Yield and Bacterial and Fungal Communities in the Rhizosphere and NonRhizosphere. Pol. J. Environ. Stud. 2009, 18, 255-263.

13. Jain, S.; Vaishnav, A.; Kasotia, A.; Kumari, S.; Gaur, R.K.; Choudhary, D.K. Rhizobacterium-mediated growth promotion and expression of stress enzymes in Glycine max L. Merrill against Fusarium wilt upon challenge inoculation. World J. Microbiol. Biotechnol. 2014, 30, 399-406. [CrossRef] [PubMed]

14. Jain, S.; Kumari, S.; Vaishnav, A.; Choudhary, D.K.; Sharma, K.P. Isolation and characterization of plant growth promoting bacteria from soybean rhizosphere and their effect on soybean plant growth promotion. Int. J. Adv. Sci Technol Res. 2016, 5, 397-410.

15. John, R.P.; Tyagi, R.; Prévost, D.; Brar, S.K.; Pouleur, S.; Surampalli, R. Mycoparasitic Trichoderma viride as a biocontrol agent against Fusarium oxysporum f. sp. adzuki and Pythium arrhenomanes and as a growth promoter of soybean. Crop. Prot. 2010, 29, 1452-1459. [CrossRef]

16. Horner, N.R.; Grenville-Briggs, L.J.; Van West, P. The oomycete Pythium oligandrum expresses putative effectors during mycoparasitism of Phytophthora infestans and is amenable to transformation. Fungal Biol. 2012, 116, 24-41. [CrossRef]

17. Ikeda, S.; Shimizu, A.; Shimizu, M.; Takahashi, H.; Takenaka, S. Biocontrol of black scurf on potato by seed tuber treatment with Pythium Oligandrum. Biol. Control. 2012, 60, 297-304. [CrossRef]

18. Al-Sheikh, H. Two pathogenic species of Pythium: P. aphanidermatum and P. diclinum from a wheat field. Saudi J. Biol. Sci. 2010, 17, 347-352. [CrossRef]

19. Al-Sheikh, H.; Abdelzaher, H.M. Occurrence, identification and pathogenicity of Pythium aphanidermatum, P. diclinum, P. dissotocum and Pythium" Group P" isolated from Dawmat Al-Jandal Lake, Saudi Arabia. Res. J. Environ. Sci. 2012, 6, 196. [CrossRef]

20. Nzungize, J.R.; Lyumugabe, F.; Busogoro, J.-P.; Baudoin, J.-P. Pythium root rot of common bean: Biology and control methods. A review. BASE 2012, 16, 405-413.

21. Fukuta, S.; Takahashi, R.; Kuroyanagi, S.; Miyake, N.; Nagai, H.; Suzuki, H.; Hashizume, F.; Tsuji, T.; Taguchi, H.; Watanabe, $\mathrm{H}$. Detection of Pythium aphanidermatum in tomato using loop-mediated isothermal amplification (LAMP) with species-specific primers. Eur. J. Plant Pathol. 2013, 136, 689-701. [CrossRef]

22. Elnaghy, M.; Abdelzaher, H.; Shoulkamy, M.; Sayed, S. Ecological studies on Pythium species associated with some plants rhizosphere in El-Minia, Egypt. J. Pure Appl. Microbiol. 2014, 8, 195-204.

23. MA Abdelzaher, H.; Kageyama, K. Diversity of aquatic Pythium and Phytopythium spp. from rivers and a pond of Gifu city, Japan. Nov. Res. Microbiol. J. 2020, 4, 1029-1044. [CrossRef]

24. Maurya, S. Biological control a sustainable approach for plant diseases management: A review. J. Pharmacogn. Phytochem. 2020, 9 , $1514-1523$.

25. Abdelzaher, H. Negative interaction between tomato growth-promoting Pythium oligandrum and the damping-off pathogen Pythium aphanidermatum. In Proceedings of the Annual Meeting of Phytopathological Society of Japan, Gifu, Japan, 5 February 2011; pp. 27-29.

26. Nzungize, J.; Gepts, P.; Buruchara, R.; Buah, S.; Ragama, P.; Busogoro, J.; Baudoin, J.-P. Pathogenic and molecular characterization of Pythium species inducing root rot symptoms of common bean in Rwanda. Afr. J. Microbiol. Res. 2011, 5, 1169-1181.

27. Le Floch, G.; Vallance, J.; Benhamou, N.; Rey, P. Combining the oomycete Pythium oligandrum with two other antagonistic fungi: Root relationships and tomato grey mold biocontrol. Biol. Control. 2009, 50, 288-298. [CrossRef]

28. Moustafa, S.M.N. Influence of Pythium oligandrum on Mycelia and Production of Zoo-and Oo-spores of Two Phytopathogenic Pythium spp. J. Pure Appl. Microbiol. 2019, 13, 233-240. [CrossRef]

29. You, X.; Barraud, J.; Tojo, M. Suppressive effects of Pythium oligandrum on soybean damping off caused by P. aphanidermatum and P. myriotylum. Annu. Rep. Kansai Plant. Prot. Soc. 2019, 61, 9-13. [CrossRef]

30. Gerbore, J.; Benhamou, N.; Vallance, J.; Le Floch, G.; Grizard, D.; Regnault-Roger, C.; Rey, P. Biological control of plant pathogens: Advantages and limitations seen through the case study of Pythium Oligandrum. Environ. Sci. Pollut. Res. 2014, 21, 4847-4860. [CrossRef]

31. Boumaaza, B.; Benkhelifa, M.; Belkhoudja, M. Effects of two salts compounds on mycelial growth, sporulation, and spore germination of six isolates of Botrytis cinerea in the western north of Algeria. Int. J. Microbiol. 2015, 2015, 1-8. [CrossRef]

32. Senda, M.; Kageyama, K.; Suga, H.; Lévesque, C.A. Two new species of Pythium, P. senticosum and P. takayamanum, isolated from cool-temperate forest soil in Japan. Mycologia 2009, 101, 439-448. [CrossRef]

33. Jiang, Y.; Haudenshield, J.; Hartman, G. Characterization of Pythium spp. from soil samples in Illinois. Can. J. Plant. Pathol. 2012, 34, 448-454. [CrossRef]

34. Bellemain, E.; Carlsen, T.; Brochmann, C.; Coissac, E.; Taberlet, P.; Kauserud, H. ITS as an environmental DNA barcode for fungi: An in silico approach reveals potential PCR biases. BMC Microbiol. 2010, 10, 1-9. [CrossRef] [PubMed]

35. Kageyama, K.; Suzuki, M.; Priyatmojo, A.; Oto, Y.; Ishiguro, K.; Suga, H.; Aoyagi, T.; Fukui, H. Characterization and identification of asexual strains of Pythium associated with root rot of rose in Japan. J. Phytopathol. 2003, 151, 485-491. [CrossRef] 